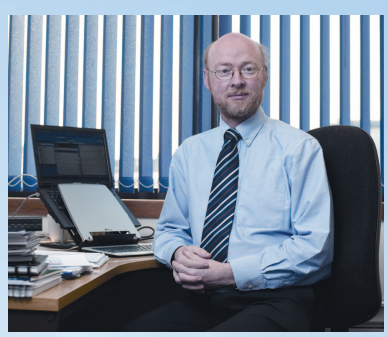

Dr. Kieran Breen is Director of Research and Innovation at Parkinson's UK, headquartered in London, which is the largest charity funder of Parkinson's research in the UK. To date the group has invested over $\$ 82$ million ( $f 50$ million) in groundbreaking research. By 2014, that figure is expected to reach more than $\$ 122$ million ( $£ 75$ million). The research funded by Parkinson's UK is intended to advance understanding of the disease and its cause, as well as to improve treatments to make life easier for those living with Parkinson's. Dr. Breen shares with STEM CELLS an overview of the organization's initiatives and ambitious research strategy, designed to push the search for a cure for Parkinson's to new levels.

Received November 29, 2011; accepted December 1, 2011; first published online in SCTM EXPRESS January 26, 2012.

(C)AlphaMed Press 1066-5099/2012/\$30.00/0

http://dx.doi.org/ 10.5966/ sctm.2011-0060

\title{
Parkinson's UK: Pushing the Search for a Cure to New Levels
}

\author{
Dr. Kieran Breen
}

\section{INTRODUCTION}

Every hour, someone in the UK is told they have Parkinson's disease. Because we are here, no one has to face Parkinson's alone. We bring people with Parkinson's, their caregivers, and their families together via our network of local groups, our website, and our free confidential helpline. Specialist nurses, our supporters, and staff provide information and training on every aspect of Parkinson's.

As the UK's Parkinson's support and research charity, we are leading the work to find a cure, and we are closer than ever. We also campaign to change attitudes and demand better services.

Parkinson's UK's fight against the disease began in 1969 when Mali Jenkins founded the Parkinson's Disease Society. Her sister, Sarah Jenkins, had been living with Parkinson's for some years and was cared for at the family home.

Mali looked for patient associations to help people affected by Parkinson's, but searches of local libraries showed that no such thing existed. Frustrated to find no literature in layman's terms about her sister's condition, Mali decided to find out what she could about Parkinson's. She placed advertisements in the personal columns of a couple of newspapers asking people to come forward who were interested in forming an exploratory steering group. Mali chaired the committee, and her sister, Eryl, was secretary. Other friends and family were asked to help.

The first meeting took place at Westminster Hospital with just 16 people in attendance. But that event spawned the idea for a national charity dedicated to helping Parkinson's patients and their caregivers-the Parkinson's Disease Society, which officially began on February 26, 1969. Today, the organization has grown to include $\sim 350$ groups spread across the UK dedicated to offering friendship and support to everyone affected by Parkinson's. In 2010 we changed our name to Parkinson's UK to reflect our expanded mission, which includes funding research aimed at finding a cure.

Along with being at the forefront of developing induced pluripotent stem (iPS) cells, Parkinson's UK has played a key role in campaigning for the implementation of legislation to allow stem cell research to be carried out within the UK, includ- ing the 2001 amendment by the British Parliament to the Human Fertilisation and Embryology Act 1990. We also campaigned in 2009 for legislation to allow for the use of cytoplasmic hybrid embryonic stem cells. We are members of the UK Stem Cell Funders Forum, which monitors developments in stem cell technology and ensures that the legislation is appropriate for these technologies to develop.

\section{Major Breakthroughs and Patient Expectations}

Parkinson's UK is currently funding a number of clinical trials, including the diagnosis and treatment of the non-motor symptoms of Parkinson's including sleep problems, anxiety, depression, and memory problems. We are also supporting research into understanding why people with Parkinson's have balance problems and are more likely to experience falls.

Although stem cell therapy is not yet available for people with Parkinson's, Parkinson's UK is working with several research groups to bring it into the clinic. In particular we have developed a number of clinical studies where fibroblasts can be taken from people with Parkinson's during their routine clinical assessment. These can be stored and ultimately be reprogrammed into stem cells, from which they can be converted into nerve cells. This both holds hope for the development of new therapies and allows researchers to study nerve cells identical to those in the brain of a person with Parkinson's.

However, one of our key research projects is to assess the stability and safety of such cell lines. Although most people are realistic about the fact that stem cell therapy will not be available in the immediate future, the operation of unlicensed clinics has raised expectations inappropriately. Such facilities are a serious concern as their therapies are usually not based on peer-reviewed published studies. Consequently, the therapies

\section{PARKINSON'S ${ }^{\mathrm{UK}}$ CHANGE ATTITUIDES. FINIDACUIRE. JOIN US.}


offered are seldom of any benefit for people with Parkinson's and can even endanger the patient's health further.

\section{Stem Cell Funding Priorities}

Our main funding priority over the next few years is focused on developing appropriate forms of stem cells that can be used for transplantation. Although iPS cells hold great promise, there are still some safety issues. Therefore, Parkinson's UK continues to fund a number of areas of stem cell research to ensure that all avenues remain open in the hope that one will result in a viable therapy for Parkinson's and could ultimately lead to a cure for the condition.

\section{To Attract Donors' Continued Support, the Organization Relies on a Key Fundraising Tool-Results}

We know that if donors see evidence that their contributions are helping move research discoveries closer to the clinic and to helping actual patients, they are more likely to continue to support the research. Researchers regularly attend events to provide our supporters with an update on the research that Parkinson's UK is funding and how it is helping to advance the field.

Such support will be critical over the next five years as we work to raise over $\$ 180$ million ( $f 110$ million) to meet the goals of our current strategic plan. This is money that will be put to work finding a cure and improving the lives of everyone affected by Parkinson's. We are more determined than ever.

\section{Meet Dr. Kieran Breen, Ph.D}

Dr. Kieran Breen has been director of research and innovation at Parkinson's UK since April 2005, where his primary role is to stimulate and coordinate the organization's funded research within the UK. He also serves on the council of the Association of Medical Research Charities, a position he has held since 2006. He previously served as coordinator of the Alzheimer's Disease Research Centre in Dundee/Edinburgh and as senior lecturer in biochemical psychiatry at the University of Dundee, where he also directed the multidisciplinary, dementia-focused neuroscience laboratory. He has been a visiting research scientist with the CNRS/CEA in France and a Senior Research Fellow at University College, Dublin, where he was awarded a prestigious Newman Fellowship to permit the establishment of a vibrant international research group. He has 64 peer-reviewed research publications, four reviews, and four book chapters. He has also served as an external expert for the European Commission and the Australian Medical Research council in addition to UK charity advisory boards and editorial panels. Dr. Breen earned his Ph.D. in pharmacology from University College Dublin after receiving a Bachelor of Science degree there in toxicology and pharmacology. 